\title{
The Effect of Plumbum, Zinc and Zinc Ratio on Plumbum in Children's Temperament
}

\author{
Yunias Setiawati $^{1}$, Joni Wahyuhadi ${ }^{2}$, H.J. Mukono ${ }^{3}$, Endang Warsiki ${ }^{1}$, \\ Izzatul Fitriyah $^{1}$, Archie A. Dwiyatna ${ }^{4}$, Andronikus Dharmawan ${ }^{4}$ \\ ${ }^{1}$ Associate Professor Department of Psychiatry, Lecturer Universitas Airlangga, Surabaya, Indonesia, ${ }^{2}$ Associate \\ Professor, Department of Neurosurgery, Lecturer Universitas Airlangga, Surabaya, Indonesia, ${ }^{3}$ Professor Faculty \\ of Public Health, Universitas Airlangga, Surabaya, Indonesia, ${ }^{4}$ Faculty of Medicine, Universitas Airlangga, \\ Surabaya, Indonesia
}

\begin{abstract}
Introduction: Plumbum is a heavy metal that is neurotoxic in children. Plumbum exposure in slum and densely populated environments adversely affects physical growth, nervous system development, memory disorders and learning disorders, cognitive deficits, psychological disorders and negative temperament of children that persist until adulthood. Zinc is an important trace element in the body. Increased free radical production and oxidative stress can interfere with homeostasis trace elements. Trace element zinc plays an important role in the mechanism of oxidants and antioxidants in microorganisms.
\end{abstract}

Method: This study is an analytical study with a cross-sectional design with sampling using the random sampling method in grade 3 to 6 grade BK Surabaya elementary school. Measuring plumbum and zinc levels using hair media was measured by the Atomic Absorption Spectrophotometry (AAS) and temperament measurements using the Indonesia's Children's Temperament Questionnaire.

Results and Discussions: Disorders of elemental levels and elemental imbalances will result in oxidative cellular component damage associated with the child's negative temperament which adversely affects communication with parents, siblings with peers and poor academic performance. This disorder can be sustained in adolescence with clinical manifestations of aggressiveness, behavioral disorders and substance abuse and in adulthood the negative impact of difficulty finding work and poor communication in the family.

Conclusions: $\mathrm{Pb}$, Zinc, the ratio of zinc to Plumbum is significant to the child's temperament.

Keywords: Child temperament, plumbum, zinc, zinc/plumbum ratio.

\section{Introduction}

Plumbum exposure in the environment adversely affects children because plumbum is neurotoxic and affects the development of the brain area of the prefrontal

\section{Corresponding Author: Yunias Setiawati}

Associate Professor Department of Psychiatry, Lecturer Universitas Airlangga, Surabaya, Indonesia e-mail: yunias.setiawati@gmail.com cortex, basal ganglia, hippocampus and cerebellum ${ }^{(1,2)}$. The highest target for plumbum exposure is the central nervous system area. Chronic plumbum exposure adversely affects physical growth, nervous system development, memory disorders and learning disorders, cognitive deficits, psychological disorders and behaviors and negative temperament of children. Infants and children at high risk of plumbum pollution with levels below $10 \mu \mathrm{g} / 100 \mathrm{ml}$ can cause impaired fetal growth and development and cognitive deficits ${ }^{(3)}$. Temperament in children is defined as a way of thinking, behaving, or reacting which is an individual characteristic and refers to the ways a person lives ${ }^{(4-8)}$ Children with 
negative temper the difficult child (difficult children) are usually very active, sensitive stimulate and have irregular habits. The negative withdrawal response is a characteristic of these children and requires a more structured environment. Children become slow to adapt to new routines, people or situations. Mood expressions are usually strong and especially negative. They often cry and frustration often leads to violent tantrums (the slow-to-warm-up) child usually reacts negatively and with mild intensity to new stimuli and unless pressed, slowly adapts to repeated contact.They only respond with mild rejection but are passive to something new or foreign or changes in routine. Children are quite inactive and moody but only show moderate disorder in terms of function.Children are more susceptible to behavioral problems at the beginning and middle of childhood ${ }^{(7)}$. Negative temperament is associated with emotional and behavioral disorders that require clinical attention because they can be sustained until adulthood ${ }^{(9)}$. Given the magnitude of the impact of plumbum exposure on the negative temperament of children as an observer of mental health of children and adolescents, it is considered necessary to conduct research to prevent the risk of children's and adolescent behavioral disorders and personality disorders as adults which burden my family and the surrounding environment

\section{Method}

This study was an observational analytic study with cross-sectional design using random sampling method in grade 3 to 6 grade B K Surabaya elementary school with a sample of 44 children. Before the research was conducted, researchers with the help of the principal and class teacher met with parents and students to provide an explanation of the research procedures and provide information for consent and informed consent that must be filled by the respondent. Inclusion criteria for research subjects were children aged 9-12 years no organic disturbances were found, mothers of children with at least junior high school education could communicate Indonesian, patients cooperatively and not experience severe psychosocial stressors. $\mathrm{Pb}$ and zinc examination was taken from cutting 10 pieces of children's hair in the occipital area close to the scalp, then the Atomic Absorption Spectrophotometry (AAS) method and temperament measurements were examined using the Children's Temperament Questionnaire. Sampling from hair based on growth is not invasive, provides a child's sense of comfort and the levels of plumbum and zinc in the hair stay longer so they can accurately identify $\mathrm{PB}$ and Zink levels ${ }^{(10-12)}$. $\mathrm{Pb}$ value, $\mathrm{Zn}, \mathrm{Pb} / \mathrm{Zink}$ ratio in the form of numerical data and statistical analysis with normality test with results $p<0.05$, which means that the distribution is not normal so that in the correlation test using the Spearman correlation test.The child's temperament questionnaire which was validated by Rini Harahap in 2013 and has been used for both research and clinical needs (Harapan, 2014) consisted of 15 questions consisting of positive and negative statements.Positive statements consist of 11 statements, namely statements with numbers $1,2,3,4,5,6,7,8,9,10$ and 11 . The choice form of positive statements is always valued (SL), sometimes (KK) and never (TP), with a score of 1-3. Score 1 is never, score 2 is sometimes, score 3 is always. While the negative statement consists of 4 statements on numbers 12, 13, 14 and 15.Negative statement choices are always (SL), sometimes (KK) and never (TP), with a score of $1-3$. Score 1 is always, score 2 is sometimes, score 3 is never. The lowest total score is 15 and the highest score is 45 . Scoring interpretation is a total score of 15-24 = difficult, a total score of 25-34 = slow and a score of $35-45=$ eas.

\section{Results and Discussions}

Table 1: Demographic Data of the Childrenin BK Surabaya Elementary 2019

\begin{tabular}{|l|l|c|c|}
\hline Variable & Category & Frequency & $\mathbf{\%}$ \\
\hline \multirow{2}{*}{ Age } & $\leq 12$ years & 41 & $93,18 \%$ \\
\cline { 2 - 4 } & $>12$ years & 3 & $6,82 \%$ \\
\hline \multirow{2}{*}{ Gender } & Female & 13 & $29,55 \%$ \\
\cline { 2 - 4 } & Male & 31 & $70,45 \%$ \\
\hline \multirow{2}{*}{ Birth Order } & First Child & 24 & $54,55 \%$ \\
\cline { 2 - 4 } & Others & 20 & $45,45 \%$ \\
\hline
\end{tabular}




\begin{tabular}{|l|l|c|c|}
\hline Variable & Category & Frequency & $\mathbf{\%}$ \\
\hline \multirow{3}{*}{ History of violence in childhood } & Never & 40 & $90,91 \%$ \\
\cline { 2 - 4 } & Yes & 4 & $9,09 \%$ \\
\hline \multirow{3}{*}{ Temperament } & Difficult & 3 & $6,82 \%$ \\
\cline { 2 - 4 } & Slow & 35 & $79,55 \%$ \\
\cline { 2 - 4 } & Easy & 6 & $13,64 \%$ \\
\hline
\end{tabular}

Table 1 obtains the highest age results of less than 12 years at $93.18 \%$ with male sex at $70.54 \%$, the order of the first high-ranking child is $54.55 \%$ and the most temperament of the child is the slow temperament of $79.55 \% . \mathrm{Pb}, \mathrm{Zn}, \mathrm{Pb} / \mathrm{Zink}$ ratios are numerical data and have been tested by normality test with the results of $p$ $<0.05$, which means that the distribution is abnormal so that the correlation test uses the Spearman correlation test with the following results:

Table 2: Correlation between $\mathrm{Pb}$, Zink, $\mathrm{Pb} / \mathrm{Zink}$ ratio with the children's temperament in $\mathrm{B} K$ Surabaya Elementary 2019

\begin{tabular}{|l|c|}
\hline \multirow{2}{*}{ Spearman Correlation } & Temperament Score \\
\cline { 2 - 2 } & $\mathbf{r}$ - value \\
\hline $\mathrm{Pb}$ & $-0,078$ \\
\hline $\mathrm{Zn}$ & $-0,325^{*}$ \\
\hline $\mathrm{Pb} / \mathrm{Zn}$ & 0,208 \\
\hline
\end{tabular}

*. Correlation is significant at the 0.05 level (2-tailed).

**. Correlation is significant at the 0.01 level (2-tailed).

Most child respondents are slow temperament. Temperament in children is defined as a way of thinking, behaving, or reacting which becomes individual characteristics and refers to the ways a person goes through life.

The classification of temperaments in children is divided into three, namely The Easy Child, The Difficult Child, The Slow-to-warm-up child ${ }^{(13,14)}$ The Easy Child (easy child) children are more relaxed and temperamental, have regular and predictable habits and have a positive approach to new stimuli. Children are more open and can adapt to changes and show the intensity of moods that are mild to moderate which are usually positive ${ }^{(15)}$ The Difficult Child (difficult child) children have a difficult temper usually very active, sensitive and have irregular habits. The negative withdrawal response is a characteristic of these children and requires a more structured environment. Children become slow to adapt to new routines, people or situations. Mood expressions are usually strong and especially negative. They often cry and frustration often leads to violent tantrums ${ }^{(16)}$ The Slow-to-warm-up child usually reacts negatively and with mild intensity to new stimuli and unless pressed, slowly adapt to repeated contact. They only respond with mild rejection but are passive to something new or foreign or changes in routine. Children are not quite active and moody but only show moderate disorder in terms of function. Children are more susceptible to behavioral problems at the beginning and middle of childhood ${ }^{(13,17)}$. Parenting is a process of introducing and supporting a child's physical, emotional, social and intellectual development from a baby to an adult.. Another aspect is that parenting is the interaction between children and caregivers during care, including the process of developing appropriate knowledge and skills for children, ways to educate by giving rules and restrictions applied to their children, maintenance, instilling trust, how to get along, attitudes create an emotional atmosphere, protection and teach general behavior that can be accepted by society. Socioeconomic status affects many aspects of parenting. Low income families limit the purchase of goods needed in parenting, such as educational games and books that are beneficial for child development. Poverty and economic insecurity affect the mental health of parents in relation to non-supportive childcare ${ }^{(18,19)}$. Slow temperament can be caused by a lack of parental stimulation due to family economic limitations and the impact of slum environments with high air pollution.

Stressful conditions in parents can potentially damage parents' attitudes and behavior towards children. Parental stress can come from various forms, such as financial difficulties, lack of social support and marriage problems. Stressors have a negative impact on the general well-being and health of parents and 
seize their attention and emotional energy. Parental stress can reduce involvement, attention, patience and tolerance for children and increase the use of punitive practices. ${ }^{(20)}$ The results of the study stated that the majority of children did not experience childhood trauma while the results of the most temperament were slow temperament. These results can explain the theory of Stella Chest that since childhood children have their own responses. Easy child child, easy to adapt to children environment difficult child difficult to adapt to environment, dissident while child slow to warm up is marked by indifference to the surrounding environment. Children also play a role in their own development. Temperament's interactions and environment are known as good and fit. The results of the study concluded that there was a significant relationship between zinc levels and the child's temperament, but no significant results were found between the plumbum level and the child's temperament. These results are not in accordance with the theory that plumbum is neurotoxic and the risk of brain damage in children with clinical manifestations of learning disorders, memory disorders and disorders of emotional control, irritability, irritability and chronic and high levels of exposure can cause death.The results of this study still require special attention considering the location of the living and living areas of slums, the pattern of care that does not provide stimulation and limited facilities and infrastructure, because the interaction of these factors negatively affects the child's growth process in the form of mental emotional disorders that can continuing until adolescence and adulthood which results in a burden on the family and the environment. The ratio of $\mathrm{Zinc}$ to $\mathrm{Pb}$ in child respondents in the study showed meaningless results. Measurement of Zinc ratio to $\mathrm{Pb}$ is a new study that has never been done before ${ }^{(21-24)}$ The rationale of this study is based on the $\mathrm{Pb}$ mechanism into the body by binding to calmodulin and blocking the N-methyl-D-aspartate enzyme which will damage brain neuroplasticity and cause encephalopathy and edema in the cerebellum region, this damage is irreversible. Plumbum will inhibit tyrosine synthesis into dopamine, resulting in reduced attention function, visual motor reasoning skills and reading, numeracy and math skills. ${ }^{(25-26)}$ Plumbum also inhibits the synthesis of tryptophan into serotonin, resulting in symptoms of hyperactivity and impulsivity. ${ }^{(27)}$ Zinc is an important trace element and plays a major role in the synthesis of neurotransmitters in central nervous system. ${ }^{(28-29)}$ Zinc plays a role in the synthesis of dopamine, serotonin and norepinephrine neurotransmitters and increases
GABA (amino-amino butyric acid) which functions as inhibitory/relaxation neurotransmitters. ${ }^{(24,25)}$

\section{Conclusions}

The results showed significant results between zinc and child's temperament. Zinc plays a role in the metabolism of melatonin which is the basic ingredient of tyrosine. Melatonin is a hormone secreted by the pineal glandule and is tasked with regulating the rhythm of the circadian cycle which is responsible for regulating the human sleep cycle. Children with emotional disorders often experience sleep disorders that are thought to be caused due to melatonin deficiency ${ }^{(17,29)}$. Zinc also acts as a precursor in the synthesis of tryptophan. High $\mathrm{Pb}$ levels will aggravate children's emotional disturbances characterized by increased symptoms of hyperactivity, impulsivity, motor, cognitive impairment and decreased academic performance ${ }^{(28,30)}$

Ethical Clearance: taken from Health Research Ethics Committee Faculty of Public Health Airlangga University No. 657KEPK

\section{Source of Funding: Self}

\section{Conflict of Interest: nil}

\section{References}

1. Rodríguez-barranco M, Lacasaña M, Aguilargarduño C, Alguacil J, Gil F, González-alzaga B, et al. Science of the Total Environment Association of arsenic, cadmium and manganese exposure with neurodevelopment and behavioural disorders in children: A systematic review and meta-analysis. 2013;455:562-77.

2. Curran EA, O’Neill SM, Cryan JF, Kenny LC, Dinan TG, Khashan AS, et al. Research Review: Birth by caesarean section and development of autism spectrum disorder and attention-deficit/ hyperactivity disorder: A systematic review and meta-analysis. J Child Psychol Psychiatry Allied Discip. 2015;56(5):500-8.

3. Luo W, Ruan D, Yan C, Yin S, Chen J. NeuroToxicology Effects of chronic lead exposure on functions of nervous system in Chinese children and developmental rats. 2012;33:862-71.

4. Baranowska-Bosiacka I, Gutowska I, Rybicka M, Nowacki P, Chlubek D. Neurotoxicity of lead. Hypothetical molecular mechanisms of synaptic function disorders. Neurol Neurochir Pol. 
2012;46:569-78.

5. Daneshparvar M. The Role of Lead Exposure on Attention-Deficit/Hyperactivity Disorder $队$ in Children : A Systematic Review. 2016;1-14.

6. Zeng X, Xu X, Boezen HM, Huo X. Chemosphere Children with health impairments by heavy metals in an e-waste recycling area. Chemosphere [Internet]. 2016;148:408-15. Available from: http://dx.doi. org/10.1016/j.chemosphere.2015.10.078

7. Brochin R, Leone S, Phillips D, Shepard N, Zisa D, Angerio A. The Cellular Effect of Lead Poisoning and Its Clinical Picture. Heal Sci J. 2008;5(2):1-8.

8. Villagomez A, Ramtekkar U. Iron, Magnesium, Vitamin D and Zinc Deficiencies in Children Presenting with Symptoms of Attention-Deficit/ Hyperactivity Disorder. Children [Internet]. 2014;1(3):261-79. Available from: http://www. mdpi.com/2227-9067/1/3/261/

9. Elbaz F, Zahra S, Hanafy H. Magnesium, zinc and copper estimation in children with attention deficit hyperactivity disorder. Egypt J Med Hum Genet [Internet]. 2017;18(2):153-63. Available from: http://dx.doi.org/10.1016/j.ejmhg.2016.04.009

10. Iris RFÆ, Sam MÆ. ADHD, Temperament and Parental Style as Predictors of the Child' $s$ Attachment Patterns. 2006;103-14.

11. Foley M, Graham S, Castellanos FX. The relationship between attention deficit hyperactivity disorder and child temperament $\square .2008 ; 29: 157-69$.

12. Hassan M KW. Daat13I1P155.Pdf. Delphi Psychiatry J. 2013;16 no 1:155-9.

13. McClowry SG, Rodriguez ET, Koslowitz R. Temperament-based intervention: Re-examining goodness of fit. Int J Dev Sci. 2008;2(1-2):120-35.

14. Ã DB, Affuso G, Trotta T. Temperament, ADHD and Peer Relations Among Schoolchildren : The Mediating Role of School Bullying. 2008;34(May):447-59.

15. Pauw SSW De, Mervielde I. The Role of Temperament and Personality in Problem Behaviors of Children with ADHD. 2011;277-91.

16. Zinc H, Analysis L, Micronutrients $C$, Growth P. Hair Zinc Level Analysis and Correlative Micronutrients. 2016;19(4):259-68.

17. Tippairote $\mathrm{T}$, Temviriyanukul $\mathrm{P}$, Benjapong $\mathrm{W}$. Hair Zinc and Severity of Symptoms Are Increased in Children with Attention Deficit and Hyperactivity
Disorder : a Hair Multi-Element Profile Study. 2017;

18. Harahap DR. Hubungan pola asuh orangtua dengan temperamen anak usia sekolah dasar di desa tanjungrejo dusun XI kecamatan Pencut seri tuan kabupaten deli serdang. 2014.

19. Chung D. The Eight Stages of Psychosocial Protective Development: Developmental Psychology. J Behav Brain Sci. 2018;08(06):36998.

20. Dwi Siswanto. Pengaruh Pandangan Hidup Masyarakat Jawa Terhadap Model Kepemimpinan. J Filsafat. 2010;20(3):7-8.

21. Susetyo DPB, Widiyatmadi HME. Konsep Self Dan Penghayatan Self Orang Jawa. Psikodimensia [Internet]. 2014;13(1):47. Available from: file:///C:/ Users/User/Downloads/Documents/277-550-1SM.pdf

22. Justin ST. Identity Development Throughout the Lifetime: An Examination of Eriksonian Theory. Grad J Couns Psychol [Internet]. 2009;1(2). Available from: http://epublications.marquette.edu/ cgi/viewcontent.cgi?article $=1030 \&$ context $=$ gjcp

23. Abulizi X, Pryor L, Michel G, Melchior M, Van Der Waerden J, Annesi-Maesano I, et al. Temperament in infancy and behavioral and emotional problems at age 5.5: The EDEN mother-child cohort. PLoS One. 2017;12(2):1-17.

24. Scheper FY, Majdandžić $M$, van de Ven PM, Jansen LMC, Doreleijers TAH, Schuengel C, et al. Temperament Traits and Psychopathology in Young Clinically Referred Children Compared to a General Population Sample. Child Psychiatry Hum Dev. 2017;48(6):841-50.

25. Rutering J, Ilmer $\mathrm{M}$, Recio A, Coleman $\mathrm{M}$, Vykoukal J, Alt E, et al. $\square \square \square \square \square \square$ HHS Public Access. 2016;5(6):1-8.

26. Mervielde I, De Pauw SSW. Models of child temperament. Handb temperament [Internet]. 2012;(October):21-40. Available from: http:// search.ebscohost.com/login.aspx?direct=true $\quad \&$ AuthType=ip,shib,cpid \& custid=s6264444 \& $\mathrm{db}=$ psyh \& $\mathrm{AN}=2012-22484-002 \&$ site $=$ ehost-live $\&$ scope $=$ site

27. Macedoni-luk M, Gosar D, Bjørklund G, Ora J, Kodri J. Levels of Metals in the Blood and Specific Porphyrins in the Urine in Children with Autism Spectrum Disorders. 2014; 
28. Marques RC, Bernardi JVE, Dórea JG, De Fatima R Moreira M, Malm O. Perinatal multiple exposure to neurotoxic (lead, methylmercury, ethylmercury and aluminum) substances and neurodevelopment at six and 24 months of age. Environ Pollut. 2014;187:130-5.
29. Levels of metals $(\mathrm{Cd}, \mathrm{Pb}, \mathrm{Cu}$ and $\mathrm{Fe})$ in cow' $\mathrm{s}$ milk, dairy products and hen 's eggs from the West Bank, Palestine. 2012;19(3):1089-94.

30. Canli M. The relationships between heavy metal $(\mathrm{Cd}, \mathrm{Cr}, \mathrm{Cu}, \mathrm{Fe}, \mathrm{Pb}, \mathrm{Zn})$ levels and the size of six Mediterranean fish species. 2003;121:129-36. 